\title{
The Statute and the Judge ${ }^{1}$
}

Contemporary jurisprudence is witnessing a grave crisis. It is not just that are there numerous disputes and profound discrepancies between the adopted positions. Something else is involved. Nowadays, one casts doubt on the very foundations of legal knowledge, questions the most cardinal, established views with regard to the essence of law, statute, the state, punishment, and the methods and the tasks of jurisprudence. In criminology, the dispute between the classics and the sociological school continues. In legal-political sciences theories emerge which strive to completely transform the current understanding of the state and its functions (Duguit). Philosophy of law is beginning to shift the essence of law beyond the traditionally determined boundaries, into completely separate domains (Petrażycki). The only branch of jurisprudence which relied on the most sound and lasting foundations was the province of civil law. That earliest and most highly developed legal discipline, which became the methodological paradigm for the whole of jurisprudence, was characterized by solid fundaments and lucidity of method, and the two outstanding fruits of legislative activity at the turn of the nineteenth century (German and Swiss codes) offered new proof of the productiveness of pertinent scholarly work.

1 Translated from: A. Peretiatkowicz, Prąd nowy w prawoznawstwie. Sędzia a ustawa, Kraków 1916 by Szymon Nowak and proofread by Stephen Dersley. The translation and proofreading were financed by the Ministry of Science and Higher Education under 848/2/P-DUN/2018. 
In recent years, we have seen the emergence of a new trend which has significance for the entirety of jurisprudence and is expressed with particular intensity in the studies of civil law. The trend originated from Germany and France, and has spread ever more widely among both theorists and practitioners, and is now penetrating into circles of non-lawyers, becoming a topical issue. The matter in question is not a notion, but a method. Not a difference of views over certain debatable issues, but the very goal of civil law inquiry, the path which leads to the attainment of that goal. Hence the tremendous importance of this novel direction, for as methods of civil law have been applied in other branches of jurisprudence, so a change of these methods entails a reform of jurisprudence in its entirety. A matter of such general nature is no longer restricted to civil law alone, but is now a matter to be addressed by legal philosophy. Both civil lawyers and the synthetic knowledge of the essence and tasks of law and jurisprudence should focus on resolving the above issue, for only joint consideration may bring a felicitous solution to such a complex problem. Setting out from two distinct positions, they should strive for a shared objective that constitutes the lodestar of jurisprudence: a theoretical apprehension of the matter that would simultaneously respond — as well as possible — to the practical demands of social life. The objective of this paper is to outline this new trend (for the sake of convenience referred to as "modernist"), to highlight and characterize its principal properties, and elaborate further on the essential premises, taking into account the crucial elements and requirements of law as such.

One of the theoretical underpinnings of the modern state system is found in the teachings of Montesquieu regarding the separation of power. Admittedly, it has not been consistently and fully implemented, but the principle of making judicial power independent of the legislative and the executive branches currently provides the core factor in the organization of state authority. "The political liberty of the subject," Montesquieu says, "is a tranquillity of mind arising from the opinion each 
person has of his safety. In order to have this liberty, it is requisite the government be so constituted as one man need not be afraid of another. When the legislative and executive powers are united in the same person, or in the same body of magistrates, there can be no liberty; because apprehensions may arise, lest the same monarch or senate should enact tyrannical laws, to execute them in a tyrannical manner. Again, there is no liberty if the judiciary power be not separated from the legislative and executive. Were it joined with the legislative, the life and liberty of the subject would be exposed to arbitrary control; for the judge would be then the legislator. Were it joined to the executive power, the judge might behave with violence and oppression.”2 In consequence, Montesquieu assigns judges a role which is utterly passive. They are only required to know the statutes and implement its provisions. Each adjudication is to strictly reflect a statute. Were it to evince the private opinion of the judge, one would live in a society without being aware one's obligations. It is therefore important to make the words of statutes evoke the same thought in all people. "The national judges are no more than the mouth that pronounces the words of the law, mere passive beings, incapable of moderating either its force or rigour." 3 The lawyer in the judge's chair becomes a machine, a subsuming apparatus which matches life's vicissitudes to pertinent, existing provisions.

The above conception is characteristic of the rational thought of the Enlightenment, which looked with great scepticism upon human nature, discerning only egoistic and negative elements within. In order to protect society against the licence of judges, one should make the activities of the latter independent of their character, bring the mental component (which is decisive for rationalism) to the fore, and base everything on the intellect guided by the statute. This was endorsed by the cult of laws that typified those times, which found its expression in the French constitutions and Napoleon's codifications. In statutes (created by the

\footnotetext{
2 C.L. Montesquieu, Esprit des lois, Londres 1777.

3 Ibidem.
} 
members of society themselves) many saw the political salvation of the humankind, a cure to all kinds of social ills. In the then intellectual climate, the position expounded by Montesquieu and his understanding of the tasks of a judge was, at least in principle, universally recognized and adopted.

The historical school contributed to the dethronement of statutes from the pedestal to which they had been elevated by the eighteenth century, and indicated new ways that jurisprudence should follow. Although legislative activity was not halted, the most brilliant legal minds took a historical direction, chiefly turning to studies of Roman law (Windscheid, Dernburg, Ihering). That is as far as theory was concerned. What about practice? Little changed in that respect. ${ }^{4}$ The historical school also gave the judge a passive role, acknowledging in principle that the task of the judge is to examine the intentions of the legislator. Given that a statute is only an expression of the national spirit, then it can only be duly comprehended when considering the legal past of the nation in question. Hence the significance of history of the law which preceded a particular statute and the importance of customary law. Essentially, however, Montesquieu's position underwent no change. A judge is expected to seek a solution beyond themselves, and to extract the appropriate norm from the statute in force (or, alternatively, from customary law).

That the provisions contained in statutes are binding on judges in absolute terms has been, and most likely shall remain, a certainty beyond any doubt for lawyers. ${ }^{5}$ A question nevertheless arises, namely what should be done in cases involving situations for which a statute does not provide. The legislator is not capable of regulating all the events that may take place in future, might not know the technological and eco-

4 Bülow offers some highly interesting remarks on the approach of practitioners of the historical school. O. Bülow Heitereundernste Betrachtungen über die Rechtwissenschaft, Leipzig1901.

5 Though not without exceptions. Former natural law did not recognize that principle. Opinions to the contrary, albeit few, are heard today as well. "Die Funktion des freien Rechts äussert sich als die Ausserkraftstellung des Gesetzesrechts in Ausnahmefällen.” F. Berolzheimer, Die Gefahren einer Gefühlsjurisprudenz, paper delivered at the legal-philosophical congress in June 1911. 
nomic circumstances, or the cultural and social situations that will arise in the subsequent years and centuries. Therefore, there is a tremendous number of issues (the older the statute, the more numerous they are) regarding which no intention has been expressed by the legislator. We are then faced with loopholes in the law.

However, concluding that lacunae are in evidence is admissible only from the dogmatic standpoint, in view of the sources of law which the judge draws upon when adjudicating a case. From the legal-political perspective, an applicable statute must not be wanting, considering the organization of the judiciary. After all, a judge cannot refuse to issue a verdict. Article 4 of the French code states: “The judge who refuses to judge under the pretext that law is silent, obscure or insufficient, shall be prosecuted as guilty of denial of justice.”

We thus arrive at an internal contradiction, a logical collision. The imperative of adjudicating each dispute, issuing a verdict solely on the basis of a statute and the unavoidable imperfection of each statute: those three things cannot be reconciled. Given that consistency is a fundamental postulate of jurisprudence and a prerequisite of its existence as a science, it is necessary to find a way out of the predicament.

The traditional method found a solution based on the fiction of statutory perfection (absence of gaps, completeness of the legal system). Following Montesquieu, it held that the "will of the legislator" is the only authoritative and decisive factor for the judge and the theoretical lawyer. If it is not found in the statute in an explicit form, then one should search for a "conjecturable will” which also arises from the statute. The traditional method negates the existence of lacunae in the statute, which represents a rounded whole, regulating a particular sphere of life exhaustively. Properly understood and accurately interpreted, a statute provides all the legal solutions one requires. Using various interpretive measures (extensio, restrictio, analogy based on ratio iuris, argumentum a contrario, a majori ad minus, a majori ad maius, examination of preliminary material etc.) one can always discover the correct inten- 
tion behind the statute, even though it has not been stated in explicit terms. The subtle mind of the lawyer should weave the entire intricate logical fabric, providing for all events and circumstances, as well as regulating human contentions. By way of syllogisms and abstract conceptualization, the lawyer creates a complete, exhaustive system of applicable norms, which offers answers to all the issues occurring in practical life.

That tendency was most vividly accentuated in Bergbohm6 ${ }^{6}$, who believed that acknowledging legal gaps is inadmissible, for in that case judges would themselves become a source of law. Law does not need to be supplemented from the outside, being at any given point comprehensive and complete thanks to its inner prolificacy; thanks to the capacity for "logical expansion" which satisfies all juridical needs. "This is no fiction, but an incontrovertible fact". ${ }^{7}$ Statues are not law, they merely indicate legal thoughts which a theoretician should elaborate, complement, and create a rounded legal system. If they are incapable of achieving that, it only attests to gaps in their intellect, but not in the legal system, which at all times remains a harmonious whole. If so-called gaps in the statute do exist, then they have to be filled through the "logical expansion" of the existing norms.

There has been some very lively opposition recently against the direction in jurisprudence which relies exclusively on statutes, logical paradigms and conclusions. Ihering may be considered the spiritual father and the first representative of the modernist current; initially, he subscribed to the traditional method, and it was only later that he spoke against it very forcefully and, given the times, very radically. Already in the third part of his Geist des roemischen Rechts there is a chapter devoted to the overestimation of the logical element in law. To Ihering, that cult of logic which seeks to make jurisprudence a kind of legal mathematics fails to understand the true essence of law and loses it from sight. It is not life that exists for notions, but notions for life. These are

6 C. Bergbohm, Jurisprudenz und Rechtsphilosophie, Leipzig 1892, pp. 372-393.

7 Ibidem, p. 388. 
not the demands of logic which must be reified, but postulations of life, transaction, and legal sense, irrespective of whether they appear logical or impossible. In the satirical-serious work entitled Scherz und Ernst in der Jurisprudenz (1884), the author strives to demonstrate-both through irony and in serious articulation - the consequences of the dominant juridical doctrine he calls "Begriffsjurisprudenz" (the designation has become widespread and now constitutes a negative catchword used to signify the modernist trend). Whereas Roman lawyers followed the path of consequence only as far as the boundary imposed by practical needs, and while employing their legal logic always kept life itself in mind, contemporary jurisprudence is unaware of such considerations and not infrequently arrives at a result which is thoroughly at odds with the very aim of law. Therefore, in the opening, programmatic article of the journal he published", Ihering formulates the rallying call "Durch das römische Recht über das römische Recht hinaus". This essential idea of the goal in any law, to which Ihering devoted his last, unfinished work, became the chief positive motto of the modernist trend.

One of the earliest and the most vehement opponents of the historical school and the omnipotence of the statute was Professor O. Bülow who, in numerous papers and above all in the treatise Gesetz und Richteramt (1885), drew attention to the actual significance of the judicial profession. Highlighting the role of judges in the historical development of law, the principle of the binding power of the ruling even when it contradicted a statute, and the utter impotence of legislation were it deprived of the judicial organization, he demonstrated that the position of the judges in the legal system of any society is by no means passive and receptive. In 1891, in his brilliant rectorial address concerning Werturteile und Willensentscheidungen, Rümelin argued that an element of subjective evaluation inevitably accompanies judges’ actions, by virtue of which the latter are creative rather than intellectual-mechanistic

8 R. von Jhering, Jahrbücher für die Dogmatik des heutigen römischen und deutschen Privatrechts, Jena 1857. 
in their nature, as the application of various interpretive measures is always founded on judgments regarding their value.

However, the above views failed to resonate to any great extent among contemporary lawyers, imbued as they were with the influences of the historical school. It was only very recently that a keener interest in legal-philosophical and methodological issues has been reawakened. In Germany, considerable credit in that respect is due to the works by Kohler and Stammler. The latter in particular, although not a modernist in formal terms, contributed to the development of the new current. Stammler's philosophy tends to be comprehended and assessed in varying ways. Nonetheless, his concept of “das richtige Recht” has spread very widely in Germany, leading to the recognition of the need for the "the right law."

A veritable watershed in the development of the modernist trend came with the splendid work of the French professor, Gény (a pupil of Saleilles's, one of the first representatives and propagators of the new current in France), entitled Metode d'interpretation et sources en droit prive positif (1899): a kind of gospel of the new trend in France. Based on a tremendous volume of both theoretical and practical material sourced from French courts, Gény demonstrated the possibility and necessity of reforming the methods of jurisprudence in the spirit of modern requirements. With formidable competence and circumspection, and at the same time, a keenly critical and boldly creative approach, the author advocates abandoning the fiction of the "legislative will", which does not correspond to facts, and acknowledging the undeniable existence of legal loopholes, which are to be remedied by liberal research into today's social needs (libre recherche scientifique du droit). Relying on the entirety of modern knowledge that takes the social and technological achievement of the human spirit into account, one should look for a norm which would constitute a vital (natural) law that tallies with the demands of our times. To oppose the former position, Gény advances a new motto: "Par le Code, mais au dela du Code!" 
One of the most tenacious champions of these novel ideas is professor Ehrlich, whose pamphlet Freie Rechtsfindung und freie Rechtswissenschaft (1903) gained considerable renown and became one of the ideological foundations of the modernist movement in Germany. Ehrlich finds the contemporary cult of the statute to be intrinsic to the bureaucratic state (Beamtenstaat) and believes that one should return to historical traditions (Roman, medieval, or those from the Renaissance period), when the authority and the significance of the judge carried much more weight. The new trend aspires to put forward outstanding individuals, who would contribute to the development of law and increase its influence among broad social strata.

Jurisprudence should guide judges along the correct course as they face contemporary issues; it should also examine law in its actual social manifestations. The concern should not lie solely with the wording of a regulation but with how it functions in life, with whether and how it is applied. The year 1906 saw the publication of an anonymous pamphlet: Gnaeus Flavius Der Kampf um die Rechtswissenschaft (written by Prof. Kantorowicz from Fribourg, as it later transpired), which thanks to clarity of disquisition, eloquent terms, and the fervour of the author did much to popularize the new ideas, at least among theoreticians. At the same time, it gave name to the entire movement (freirechtliche Bewegung) which was almost universally adopted in Germany. A considerable impact, particularly on German practitioners, was exerted by the writings of the advocate E. Fuchs (Recht und Wahrheit in unserer heutigen Justiz, 1908, Die Gemeinschädlichkeit der konstruktiven Jurisprudenz, 1909, and other works), who admittedly goes too far at times, but in general very aptly — based on extensive practical material — highlights the shortcomings of the method which holds sway today. As a theoretical-political manifestation of the free-law movement in jurisprudence, the Swiss code (which came into force in 1912) is particularly worthy of mention, as its first article sets forth: "Das Gesetz findet auf alle Rechtsfragen Anwendung, für die es nach Wortlaut oder Auslegung eine Bestimmung 
enthalt. Kann dem Gesetze keine Vorschrift entnommen werden, so soll der Richter nach Gewohnheitsrecht und wo auch ein solches fehlt, nach der Regel entscheiden, die er als Gesetzgeber aufstellen würde. Er folgt dabei bewahrter Lehre und Überlieferung.”

I have mentioned the most important works which in a sense represent stages in the development of the new trend, in view of their influence in various milieus. ${ }^{9}$ The final phase of the modernist movement assumed a practical dimension and reached very broad circles, well beyond the domain of the legal profession. In early 1911, two appeals were circulated, whose authors called for a reform of jurisprudence and the judicature; this resulted in the formation of two groups of modernists. The first of these was led by Bozi ${ }^{10}$ (a judge in Bielefeld), who also gathered numerous non-lawyers around him; the second was established by Börngen (president of the higher regional court in Jena). In March, both factions united by incorporating as the association Recht und Wirtschaft, whose adopted motto stated: "Forderung zeitgemässer Rechtspflege und Verwaltung." Since autumn 1911, the association published its own periodical in order to kindle interest in the issues in question among the broader public. The matter of the judge's approach to statutes was included in the agenda of the forthcoming congress of German judges, and it is to be expected that it will be resolved in a spirit which favours modernism. One could even say that legal modernism has all too many adherents, that it gained recognition too quickly, that the presence of outstanding opponents would enable the new trend to be expounded better and to become more profound. ${ }^{11}$

9 One of the eminent modernists is Prof. Zoll Junior, whose noteworthy works in this respect are little known in the West due to reasons of language.

10 The author of numerous treaties particularly Die Weltanschauung der Jurisprudenz, in which he argues that jurisprudence be made an experimental science, based on foundations derived from natural sciences. A. Bozi, Die Weltanschauung der Jurisprudenz, Hannover-Helwing 1911.

11 Modernism has an outspoken and ingenious adversary in Prof. Donati (D. Donati, Il problema delle lacune dell ordinamento giuridico, Milan 1910), who resumes Zitelmann's arguments (E. Zitelmann, A. Pestalozza Lücken im Recht, Bonn 1903), and elaborates them further. Donati holds that by linking legal effects with certain states of fact, the legal order 
We are thus confronted with a trend which is very broad and exceedingly influential with respect to methodology. At the moment, following wider practical propaganda, it has crystallized into a more distinct form and may be deemed a coherent whole. Let us then conduct a concise, legal-philosophical analysis of that new trend, consider the causes behind the emergence of the movement, its chief attributes and its outcomes - which can and should be pursued. Finally, let us delve into that aspect of the new current which may have a special significance for us, Poles. The scope of this paper does not allow the above to be discussed exhaustively, which is why I will confine myself to the essential ideas and the most important observations.

It would be a futile and unproductive endeavour to determine conclusively the actual source of the new turn in legal thought. The scientific and social currents are too complex and comprise too many elements to be considered the outcome of one single cause. One should not even speak of a causal relationship in the strict sense. After all, the relationship presupposes absolute necessity for a given effect to ensue if facts which constitute its cause have occurred. Contemporary psychology has failed to determine the causes which inevitably engender particular human thoughts, therefore when studying intellectual currents one can only speak of factors whose collusion accompanied the emergence of those currents, but we should be aware of the psychological impossibility of arriving at an accurate delineation of the entirety of such factors. In this instance as well, when trying to establish the origins of legal modernism, we may only distinguish the principal types those factors which, as it is usually the case with scientific-social currents, include intellectual considerations on the one hand, and factual elements on the other; theory one the one hand, whereas on the other-life itself.

The theoretical aspects are associated with the orientation of human thought which ever more strongly embraces contemporary philosophy

excludes the latter with respect to all other possible states. Thus, he recognized the "force of logical exclusion" as opposed to "force of logical expansion." 
and presents itself under the name of voluntarism. The intellectualism and rationalism of the Enlightenment triggered a reactionary response in the form of the psychology of emotion, which is not so much a particular trend in psychology as a general spiritual current, encompassing philosophy, literature, art, etc. That general philosophical atmosphere was also manifested in the emergence of the historical school, which bore the mark of Romanticism. By way of counterpoise to deliberate, intellectual creation, it attached primary importance to the process of the unconscious formation of law, and display cult-like reverence for folk elements, vital factors which actually operated in life. However, the emotional bias in psychology did not last long, and in more recent times we have seen a distinct tendency for will rather than intellect and emotion to come to the fore. Admittedly, voluntarism does not aspire to account for all inner experience by invoking the elements of will, as intellectualism had one-sidedly done with notions and ideas. Still, it considers that factor to be more consequential and presumes that it plays a role both in emotional and intellectual processes. A complete isolation of the intellectual elements may prove helpful in a more thorough analysis and facilitate better understanding of respective phenomena, but this process is artificial, methodical, and so does not amount to actual psychological phenomenon. The threads of inner experience are a homogeneous whole which can only be divided through abstraction, but in reality they constitute inseparable parts of a single mental entity, in which the elements of will are those of primary importance. "Other elements," Wundt observes, "are always components of the complete process of will and cannot be contradicted with will in a manner resembling the way in which the latter can be separated from notions from the standpoint of psychological analysis."12 According to Sigwart, "will has an advantage in the theoretical domain as well.”13 “All thought,” says Windelband, "remains without exception under the influence of will throughout its

12 W. Wundt, Logik der Geisteswissenschaften, Stuttgart 1908, p. 160.

13 S. Sigwart, Logik, Freiburg 1889, p. 25. 
course."14 The most extreme expression of this approach is pragmatism (James, Schiller, Jerusalem), which aspires to subject our judgments to the criterion of public interest, and the achievement of certain life's goals. This current attracts increasing numbers of adherents and begins to exert an influence on the whole of contemporary science.

It was not only philosophical thought which drew lawyers' attention to facts that made up the substrate, the fundamental premise of the new trend. It would be misguided to attribute a dominant role in the development of jurisprudence to philosophy. As we know, philosophical knowledge does not enjoy great regard among lawyers and even such an outstanding intellectual as Ihering appreciated its significance only towards the end of his life, and publicly deplored deficiencies in that respect. Still, facts and practical life appeal keenly to lawyers and their impact is much more forceful. The past century and recent years have provided plenty of such facts. Social life has probably never been as dynamic as in that period. The extensive achievements in technology, and the changing economic and cultural circumstances, generate ever new social needs and demands in the legal domain. It becomes evident that statutes fail to keep up with life. Each law is by nature conservative, and it is already obsolete when it is drafted, encapsulating the phenomena and factors operating at the moment of its creation into a permanent norm. However, it is not capable of predicting future facts and changes, nor can it be in line with new relationships. Montesquieu realized this, and therefore advised the frequent revision of laws, so that all issues which might arise could be resolved by statutes. Here, life proved theory false. It demonstrated technical obstacles and the practical impossibility of continual legal reform. Creation of the universal German code was vivid proof that very long and laborious paths lead to statutes which cover more comprehensive domains of social life. It is clear that this measure will not attain its goal and counting on the legislative apparatus

14 W. Windelband, Präludien, Aufsätze und Reden zur Einleitung in die Philosophie, Freiburg 1884, p. 265. 
alone would be ineffective. One should look for another factor which could mediate between a law and the new demands posed by life, and this function is now discharged in practice (not in theory) by the judicial estate.

On the other hand, the chasm between society and professional lawyers has become increasingly palpable. In the Roman times, in the Middle Ages and in the Renaissance the nation and the law were close; while the bond has been very much preserved in England, Central Europe witnessed the contrary: the absolute-and subsequently the constitutional—state transformed law into a system of abstract norms which were unknown to the public and served officials who enforced the orders of the omnipotent legislator. Although the historical school maintained that law is a product of the national spirit while lawyers are exponents of the soul of nation, the law was in fact shaped after the Roman model without regard for the distinct nature of the matter subjected to regulation. Apart from that, the historical school caused theory to be detached from practice, separated science from the actual administration of justice. Nineteenth-century German jurisprudence showed little interest in the regulations in force and readily concerned itself with the past, with Roman and Old Germanic times, while a similar approach pervaded the system of university studies. History was studied for its own sake, it was treated as a goal, not a means to an end. This had to change as the new code was introduced. A fair number of eminent figures diverted their attention and efforts from history to focus on the law in force, on the present day. The dissonance between science and practice gradually diminishes, giving rise to fitting demands placed on legal knowledge which formerly received so little attention.

Finally, in countries where exhaustive codification took place at an early stage, such as France or Austria, experience has shown that the existence of comprehensive laws does not suffice to ensure the stable and uniform administration of justice. Montesquieu's ideal, where “one judges today, as they will judge tomorrow, and judgments ought to 
be fixed to such a degree as to be ever conformable to the letter of the law”"15, was not realized, as it proved impracticable. Both with respect to minor affairs and matters of utmost importance, numerous theories were advanced, which on the grounds of the same state of facts arrived at divergent legal effects. The relative nature of interpretation of the regulations in force became ever more apparent. The history of the application of law demonstrates a gradual evolution, which corresponds to the development of life and its needs. The German code also contributed to exposing the limits of the legislature and disproving the legend of the "logische Geschlossenheit des Rechts" much more effectively than the numerous and dispersed sources of Roman law could have done.

All these factors, as well as many others, caused a breach in the traditional notions, engendered a kind of scepticism towards the alleged objectivity of law, and spurred a critical movement where the tasks and the methods of jurisprudence were concerned. The need for a revision of the foundations on which one had relied so far began to be perceived and acknowledged. The postulation, advanced at first by a few profound minds, aroused increasingly lively interest, and eventually transformed into a universal trend which has spread across broad circles of theoreticians and practitioners, becoming a topical issue. It is quite understandable that the modernist trend, as all novel movements, does not have such distinct foundations and clear-cut contours as the longstanding schools; that there are many extremes there, many ostensible contradictions, many groundless illusions. Let us then use the abundant literature to try and isolate the essential core, the enduring kernel inherent in all_or at least the most modernist—views which have been expressed and possess decisive significance for the entire current.

There are four crucial moments of the modernist movement, or elements of fundamental importance, which provide basis for all its other manifestations: 1) the critical-conceding moment, 2) the teleological- 
social moment, 3) the cult of individualism, 4) the idea of natural law (reformed).

The modernist current sets out from the recognition of the vital nature of jurisprudence and adjudication. ${ }^{16}$ " The fight," states Kantorowicz, one of the chief representatives of modernism, "has a declarative rather than constitutive significance." ${ }^{\text {"17 }}$ One should relinquish the illusion that a law, even the most comprehensive one, is able to provide for all the instances in which it should be applied. Civil codes endure for centuries, while life changes continually, technological and economic circumstances shift, and it is obvious that no legislator is capable of anticipating future forms that social life may assume. Could Napoleon's code have predicted the use of electricity and all the relations it would bring about? Could it have made allowances for the development of factorybased production and modern means of transportation? Even if social conditions were to remain unchanged, no legislator is so brilliant as to envision absolutely all relationships, all conflicts, and all legal needs. Life is always more profuse and more multifaceted that statutes and brings forth instances to which we can find no answer. The existence of gaps in law is a doubtless fact.

According to the traditional school, in such cases one should search for a "presumable legislative will" and fill the apparent gap by means of "logical expansion." The device which serves to do so consists of wellknown interpretation methods, which are expected to extract the correct legislative will from the law. One of the chief assertions of modernism is that the "presumable will" is a fiction which should be ousted from science, since it creates the illusion of objectivity that does not exist in reality. After all, it is simply not possible to determine the notions entertained by the legislator from a century ago. Looking for the fictitious will, the commentators actually strive to find a "rational", most "purposeful" will.

16 The modernist movement is primarily concerned with the activities of judges; however, given that scholarly jurisprudence consists largely in conducting preparatory work for the judge, both remain closely linked.

17 H. Kantorowicz, Kampf um die Rechtswissenschaft, Heidelberg 1906, p. 9. 
Thus they introduce a new moment into their deliberations, a naturally subjective component of rationality and purpose. Hence adjudication in doubtful cases usually includes expression of views regarding the "value" of one decision or another, being always a "Werturteil” (to use Rümelin's language), and conclusions founded on "will”.

The use of interpretive means in order to ascertain the legislative will appears to be a scientifically-objective process. However, this is a misconception, for there are no objective criteria as to the choice of such means. There are numerous methods of construction, but when does one use analogy and when should it be argumentum a contrario? When should the interpretation be broadening and when restrictive? What should one do when a conflict of laws arises? Which norm should be deemed to prevail? The "rationality" and "equity" of the obtained results come into play when making the choice, and thus we are dealing yet again with the subjective element, with "value judgments" and decisions based on "will."

Finally, one should realize that all statutes operate by employing notions and necessarily have to do so. Indeed, a notion is an intellectual instrument that is indispensable in order to find one's bearings in the tremendous complexity of diverse phenomena, yet it is a very inaccurate and imperfect tool. ${ }^{18}$ The substance of notions (abstract ones in particular) is virtually never delineated with such precision that it does not raise any doubt. Apart from the permanent elements inherent to each notion, there is a range of borderline points, phenomena situated at the outer limits of notions which constitute a transitional juncture and can therefore be classified in either category. A question arises here, namely what is the judge guided by as they subsume life's phenomena under this or that legal notion? Undoubtedly other factors (rightness, purposefulness) must be involved, not statutory provisions alone. Here, "value judgments" and decisions based on "will” are in evidence as well.

18 Petrażycki provides some highly valuable observations in this respect. L. Petrażycki, Wstęp do nauki prawa i moralności, Petersburg 1907. 
Consequently, legal modernism sets out from the assumption that jurisprudence and judgments possess certain properties which consist in the inability to eliminate the subjective element, the value component and the resulting will. Each issue of contention becomes a singular legal problem, for which there is no ready-made solution in statutes, but which has to be created. Fictions that are considered a reality are detrimental to science and life alike. One should critically and openly face the truth and refrain from concealing indisputable facts. Therefore, legal modernism is first and foremost critical-conceding in its approach.

The second trait of the new trend is its social nature, which is why it adopts the creed of "Die sociale Jurisprudenz" as its modern postulation instead of the traditional "Begriffsjurisprudenz" (as construed by Ihering, where it means the creation of abstract notions without taking into consideration the consequences it may lead to, compounded by their application to resolve legal questions regardless of the usefulness of the results thus obtained). Modernism emphasizes the principle of the purpose of each law, which is only a means of satisfying social needs. In view of the fact that legislation contains numerous loopholes, contradictions and inaccuracies, it should be implemented from the teleological standpoint, i.e. its rightness and social interest. A statute is not an end in itself and the logical perfection of the system is not the goal of jurisprudence. If the judge fails to find a clearly formulated provision in a statute, then they should be at complete liberty to look for the most pertinent norm. Freie Rechtsfindung! Libre recherche scientifique! It is not through abstraction and logical analysis, not by way of intricate constructions that the judge should arrive at the right decision, but through thorough knowledge of social life and its needs. Universal benefit and justice should be their directives. Thus the activity of the judge becomes analogous to legislative action, with the exception that the decision of the judge does not produce a general but a specific norm pertaining to the case it regulates. Given such broadly understood tasks of the judge, 
the duty to fulfil them adequately becomes a difficult one indeed. The judge cannot limit themselves to in-depth knowledge of laws and relevant literature, as they need to reach beyond the confines of their office and approach life itself. Only thorough knowledge of social relationships, scrupulous examination of the facts and data make a right verdict possible. It is indispensable to be conversant with the factors which yield modern culture, meaning the knowledge of both the actual political system which provides the framework for all institutions and expresses itself in laws and customs, the structure of contemporary economy, as well as moral and religious concepts which function within a society and require being taken into account. In this respect, they may avail themselves of the contemporary achievements of the human spirit and the findings of modern scientific inquiry. The lawyer should also know the yield of economics, ethics and philosophy, psychology as well as take advantage of technological sciences, so as to have a clear idea of the shape of contemporary civilization and its demands. Sociology is of paramount importance here, a science encompassing the entirety of social life which admittedly has not yet gained stable foundations and a sure method, but one of which much may be expected in the future. As Gény asserts, “one should set much less store by logic, in itself utterly fruitless if one does not combine it with real material, and turn to sciences and methods which aspire to discover the active and fertile substance by observing, analyzing, and elucidating the entire social life of humankind.” The element of interest, elaborated by Ihering, is very strongly underscored by many modernists. Resolving contentious issues presupposes understanding of the interests involved and striving to bring them into balance from the standpoint of the social good. This means granting state sanction to those interests which carry higher importance. Determination of individual rights can be best facilitated by an examination of the overall economic and social goals, and the subsequent comparison of their significance with the weight of interests that are contrary to those goals. Various teleological moments are given 
consideration in practice even today, but this usually assumes the form of a constructive dialectic and is thus hampered and distorted.

Modernists demand that social factors in the above sense are also introduced in the course of university studies. They argue against onesided historicism and the "jurisprudence of notions", insisting that present-day social relationships should be incorporated to a greater extent. One should look not only outside oneself, but also ahead of oneself and into the future. One should tend to the harmony of the system and consistency of legal constructs as well as their capacity to satisfy existing social needs. Alongside the knowledge of laws, the young lawyer should learn to understand people and social life. Psychology, political economy, sociology and their applications should be an inseparable part of legal studies. This is echoed in the demand which Ehrlich is particularly vociferous about, namely to study legal norms not only in their abstract, theoretical form, but also in real life. "A legal norm is not a rigid dogma, but a vital force.” The task of jurisprudence is to present law as it actually applies and operates. One who only knows the "will of the legislator" does not know law which exists in fact. According to Ehrlich, dogmatic understanding should be contrasted with dynamic understanding, which considers law as it operates in practice.

Social nature is also manifested in the postulation calling for the democratization of law, in order to bridge the distance between law and the wider masses. One the one hand, law should be given a form which is accessible and comprehensible to all strata, while on the other its substance should be indicative of society's legal awareness and thus nurture a close bond with the people. Current jurisprudence has turned out a class of spiritual aristocrats, a separate caste who are not understood by the general public and who do not understand the latter either. One should strive for the state which had once existed in Rome. The confidence in law and the cult of law may only ensue if there is knowledge of it. Here, the demand for "Die sociale Jurisprudenz" in lieu of "Begriffsjurisprudenz” applies as well. 
The third essential moment in legal modernism, perhaps not as definite as the previous ones but still recurring in various forms, is the conviction presuming the existence of non-positive law, a law which exists outside statutes and which should be valid for the judge when rectifying statutory loopholes. "The new understanding of law”, Kantorowicz says, "presents itself as a revival of the natural law in an altered form." 19 A curious twist of history! Repressed by the historical school, by the empiricism of the nineteenth century, by modern positivism, natural law seemed to have withdrawn from the realm of law and found shelter in the archives of the past. Towards the end of the last century, Bergbohm dedicated much of his life to the labour — fruitless, as it turned out—of searching for and detecting the remnants of that utopia hidden in various forms, so as to extirpate it from legal science once and for all. Meanwhile, today we see that doomed idea resurface with great vigour. Also, if we look back at history and realize that the idea of natural law never really disappeared, that in society, outside the sphere of professional lawyers, the idea still lives and operates, it would be legitimate to ask whether it is not a sociological fact, a social-psychological phenomenon which not only manifests itself in diverse form but is —in its essence-inseparably linked to human nature. However, we are not going to delve into that question here as it would lead us too far; let us only state that legal modernists constantly invoke non-positive law. The difference between its modern and past variants is easy to capture. It is not considered permanent, immutable, independent from the circumstances of time and place; on the contrary, it is believed to depend on economic, social and political relationships, on the level of civilizational advancement, on the culture of the given period. It does not possess binding force (as the old school maintained) on a par with or even above statutes, having merely certain ancillary significance as it fills statutory loopholes.

Determination of the positive character and positive substance of the modern natural law is less lucid, which is quite understandable consid-

19 H. Kantorowicz, Kampf um die Rechtswissenschaft, Heidelberg 1906, p. 10. 
ering the difficulties and complexities involved. Prof. Gény-who incidentally combines natural law with the principle of justice-goes farther than anyone else in this matter. He assumes the existence of certain ethical factors which endure unchanged over time. "Beyond and above the positive nature of things, composed of material and mutable elements, there exists a higher order of things which consists of changeless principles of reason and ethical factors." 20 The statute is only one of the expressions of the essential law, which can and should fulfil its role outside the statute. Kantorowicz recognizes the existence of a law "which aspires to binding force irrespective of state power" and calls it "freies Recht”. The matter is expounded in most explicit terms by Prof. Zoll, who sees "the right law" in "the principles and rules which at a given moment should, in view of the 'nature of things', be deemed as the best and the most appropriate ones, as an ideal of legal norms", while asserting that "at a given moment and in a given society there can be only one just law." ${ }^{21}$ It becomes the source of the applicable law by virtue of interpretation which should make use of it.

The very motto of the new trend, that is "Freie Rechtsfindung!", intrinsically presumes the existence of law outside the statute, one which needs to be found. Strictly speaking, one should rather speak of the "creation of law" in this case, and then "Freie Rechtsschöpfung!"22 would be a more fitting slogan.

The fourth fundamental moment of the modernist trend is a certain cult of individualism in the actions of the judge. In this respect, the new current represents a complete contrast to the age of Montesquieu, when efforts were made to extinguish any traits of individuality in the mind of the judge, and organize the judiciary in such a way that the judge would be a machine, an intermediary apparatus between statutes and the adminis-

20 F. Gény, Méthode d'interprétation et sources en droit privé positif: essai critique, Paris 1899, p. 481.

21 F. Zoll, Austriackie prawo prywatne. Część ogólna, Kraków 1909, p. 28.

22 See the valuable remarks made by Prof. Radbruch in Rechtswissenschaft als Rechtsschöpfung. G. Radbruch, Rechtswissenschaft als Rechtsschöpfung, Heidelberg 1906. 
tration of justice. Modernists repeatedly invoke the example of England and the importance that eminent judges enjoy in that country. ${ }^{23}$ They call for fewer but better selected judges, assuming that outstanding personalities will contribute more effectively to the development of law than average minds. Just as natural law in its time set the inalienable rights of a person against the state, so legal modernism juxtaposes the rigidity and formalism of state norms against the discretion of judges, who may treat each case differently, employ an individualized approach instead of a single, uniform standard. Modernism realizes that such treatment entails subjectivity and certain latitude, yet it believes that this will yield better results than the inflexibility of statutes and template-like adjudication, in which subjectivity cannot be completely eliminated either. Still, there is no doubt that this individualistic bias is associated with confidence in the present-day representatives of the judicial estate.

Besides those fundamental elements, encountered in almost all modernist treatises and uniting the adherents of the new trend into one, tightly-knit camp, there are many other postulations and views which divide the movement into internal factions. Thus, claims are made de lege ferenda: to extend the liberties of the judge by virtue of statutes themselves, to create laws in the form of general guidelines rather than detailed regulations, to launch procedural reform oriented towards the elimination of superfluous formalities, a reform of the judicial administration etc. Furthermore, some demand nationalization of the legal language, which should be made comprehensible to the broad public, ensuring older lawyers-practitioners an opportunity of further education, or elevating the social status of the judges. However, as the movement evolves, the fundamental critical-methodological elements come to the fore and gather increasing numbers of supporters, which promotes greater clarity and perspicuity.

23 Prof. Gerland demonstrates that Germans have superficial knowledge of the state of affairs in England and tend to overestimate it considerably. H. Gerland Die Einwirkung des Richters auf die Rechtsentwicklung in England, Leipzig-Berlin 1910. 
On the other hand, it has been wrongfully alleged that modernists consider it possible to adjudicate contra legem. Today, when the general lines of the new trend have already been drawn, this aspect has been set straight as well, while such revolutionary notions - which did previously exist - have been revised or withdrawn. ${ }^{24}$ It now becomes evident that that the proposed method of resolving matters was in fact praeter legem, not contra legem. It would also be unfounded to accuse modernists of seeking to eliminate notions from the legal sciences, when actually the idea is to conceive notions which respond to the social needs as efficiently as possible.

Thus far, I have discussed what occasioned the new trend, outlined its general nature and the crucial moments; I have also attempted to present its chief traits in the most objective manner possible. Now, let us assume a critical position, ask about the rationality and values of the new method with respect to the traditional approach. It should be noted, however, that I by no means pursue evaluation from the legal-political viewpoint, or seek recognition of the necessity for the method to be universally introduced or categorically rejected. The matter remains closely related to the quality of human who is to deliver judgments in accordance with the new rules, to the maturity and impartiality of the judicial estate. Consequently, one set of solutions would perhaps be preferable in the case of Russia, whereas different ones would apply in Germany, Austria or France. Thorough knowledge of the territory should be acquired before any judgments are passed.

Something else is the point here. Next to the legal-political perspective another viewpoint may be adopted, namely the new current may be examined from a legal-philosophical position, which focuses on the essence and the tasks of law. As a result, we will perceive that in order to become a truly juridical current, the modernist trend must become more profound and undergo certain modifications since, though it harbours worthwhile elements, it has failed to formulate them in sufficient detail,

24 Cf. H. Kantorowicz, Die Contra-legem Fabel, “Deutsche Richterzeitung“ 1911, no. 8. 
and goes too far in its critique of the traditional school. While preserving the teleological components, it is imperative that an objective element be introduced, so as to satisfy the requirement of legal security.

Without becoming entangled in metaphysical speculations or rationalist deductions, and relying on the popular legal awareness instead, we may observe that crucial elements of law include not only the socialstate sanction, but also two other components, namely social purposefulness and stability, and the determinacy of the normative regulations.

The weakness of the traditional school lay in a certain oversight, in reducing the first of the aforesaid legal factors-social purpose- to an inferior rank. Logic predominated, the endeavour concentrated on the consistency and harmoniousness of the system, on subtle notional analysis. In consequence, actual social needs suffered twofold: firstly because the will of the legislator was constructed using abstract categories which were often unsuited to the specific actual circumstances but did the opposite, forcing life into the mould of a formula; secondly, because the structure and the adjudication were founded on the presumable will of the legislator who was considerably remote from the current times and contemporary conditions, therefore the will could not be pertinent for the present-day relationships. Naturally, I disregard the attempts to construct the "presumable will of the legislator if they had known the conditions today", as this is a contrived procedure resting on the supposition that the legislator would have acted "rationally", whereby the latter notion is defined on the basis of one's own views.

The shortcoming of the modernist trend is that it depreciates the second factor which is nevertheless quite relevant in law, namely the stability and objectivity of the formulated norms (which rectify statutory gaps). Modernism demands that the judge be released from the shackles of the statute, but it does not specify the direction which their actions should follow, and it does not provide objective directives one could use as guidance when resolving disputable issues. Admittedly, modernists do engage in deliberation on factors that need to be taken into account 
when drafting laws, and suggest related guidelines. A considerable part of the brilliant work by Prof. Gény consists in enumerating and analyzing all those moments and circumstances which should play a role in establishing a legal norm. Undeniably, all possess certain degree of significance, but one should be aware that all are inherently subjective; even the findings of the social sciences on which Prof. Gény counts so much, once they cease to be theoretical and become practical knowledge (that is, when they no longer study what is but determine what should be), acquire subjective character. Liberal determination of the legal purpose and the subjectivity of assessment are inseparable.

A number of modernists believe that the objective aspect of created law is founded on the inquiry into the "nature of things". "The nature of things, approached as a source of positive law, hangs upon the postulation that relationships of social life harbour the capacity to keep them in balance and identify on their own, so to speak, the norm which should govern them.”25 This view is a reflection of the philosophical-sociological theory developed in France and known by the name of solidarism. The view has been fairly often expressed in recent literature, but its chief flaw is that is presumes knowledge of the essence of a given phenomenon. "The nature of things" describes not only the entirety of actual circumstances relating to a particular area, but also denotes appreciation of their significance from the standpoint of values, and this latter element must necessarily be subjective. It cannot be denied that the study of the nature of things or nature of certain phenomena reduces subjectivity insofar as it generates the knowledge of all related facts, therefore value judgments rely on the same experimental material and their discrepancy thereby is diminished. However, the conclusion that knowledge of those factual circumstances could produce only one objective norm of action is untenable. In this position, subjectivity also remains indelible.

25 F. Gény, Méthode d'interprétation et sources en droit privé positif: essai critique, Paris 1899, p. 469. 
Other modernists are more radical in their approach. They do not provide any directives nor put forward any criteria. According to them, the judge should be given absolute, unconstrained freedom. Liberated from the fetter of logical constructs, they will find the most appropriate norm on their own. "It is then that the ideal of impartiality (?) will be reified, since the partiality of the judge is due solely to the ignorance of social facts and views." ${ }^{26}$ If the judge looks towards life itself as opposed to theory, they will gain the best possible grasp and sense of the vital social needs, determine the most purposeful norm, and find the most suitable law.

However, can such a position be called a juridical one? Does it not contradict a vital quality of law, namely the stability of created norms? Is it not an acknowledgement of the unmitigated licence and subjectivity of the judge? Would it not lead to anarchy in the administration of justice? Modernists expect that taking social needs into account will result in the objectivity of adjudication. This is clearly a delusion which does not stand up to the text of experience. Even among professionals who devote themselves wholly to the study of the issue, life demonstrates a tremendous disparity of views concerning social needs and the tasks of law, not to mention the situation of a layperson. One could go as far as to say: quot capita tot sensus. If the opinions on social policy in general are so diverse, then things become even more complex when justice is administered, and not infrequently one can hardly determine the social outcome of one or another ruling. Even if the views regarding social needs are concurrent in many points, how many of those-fundamental though they are at times - are disputed? In its extreme manifestations, the modernist trend enables judges (at least in principle) to deliver judgments which blatantly contradict the foundations of the legal framework today (unless a statute stipulates expressly to the contrary), and negate the universal legal sense, only because it was deemed the most appropriate in the opinion of a given judge. The 
position of the modernists cannot be reconciled with the principle of legal security. From the social standpoint, bad regulations are preferable_-as long as they are definite and stable — to the anarchic licence of judges. Absence of any guidelines and boundaries in adjudication constitutes a major deficit in the new programme. The usual response of the modernists, namely that the traditional method does not preclude subjectivity, does not suffice, as the extent and limits of subjectivity are the chief concern here. In the traditional school, subjectivity is evinced in a different comprehension of statutes, but the goal is to align rulings as closely as possible with statutory provisions, to the ratio legis, to the spirit of the law. In the new current, subjectivity results from disparate social views. In the former case, we are dealing with limited subjectivity; in the latter, it is unlimited. ${ }^{27}$

We are thus faced with the dilemma of two directions, either of which satisfies only one of the crucial elements of law. The first safeguards legal security, the second assures social purpose. The question now arises of whether the above conflict is inevitable, whether one of those crucial elements has to be sacrificed. I believe that there is no such necessity, that the modernist trend should retain its merits of realistic-social orientation, but that it requires some elaboration, some modification in order to achieve the quality it has been lacking: objectivity. Nonetheless, if we are to resolve that issue, we need to consider the actual source of all rulings, the basis of all decisions: the psyche of the judge.

If we attempt to analyze the psychology of the judge as it operates when passing judgments, we shall find three essential components corresponding to the three facets of our spiritual life: 1) the intellect (logical reasoning), 2) feeling, and 3) will. Each of these factors plays a certain role, and although one's psychological being represents one in-

27 "The posited freedom in application of law would in reality engender-besides theoretical paralogism - a constant threat to the legal freedom of citizens, whose most fundamental pre-requisite is legal certainty and, in particular, the unassailable authority of the statute.” G. Del Vecchio, Sulla positivita come carattere del diritto, Prolusione al corso di Filosofia del diritto, Bologna 1911. 
divisible whole, in order to examine those psychological processes they need to be isolated by way of abstraction and their nature determined.

The working of the intellect consists on the one hand in comparing the state of fact with the premises expressed in the statute and, on the other, in drawing consistent conclusions from statutory provisions. It is a process of reason par excellence, which operates using logical syllogisms. This is also where the search for the legislative will takes place in those cases which are evidently not regulated. This is not a pursuit of the surmisable "rationality, purposefulness" of legislative will—as this is merely camouflaged subjectivity which introduces various elements into play, not only rational ones_-but an act of drawing conclusions by means of general principles, foundations deriving from the norms themselves, by means of the ratio legis inferred from a given statute. The orientation of this activity is the exact opposite of drawing direct conclusions from existing regulations. It is a process of logical construction which the traditional school held to be the only authoritative mode, an intellectual process devoid of any other elements. In practice, however, it seldom functions in its pure form, but tends to integrate other psychological factors.

Next to intellect, an element which contributes (consciously or unconsciously) to legal decision-making is will. It is evinced in deliberating on the goal of a given adjudication or specific norm, whilst being aware of the social aftermath that a rule determined by the judge may cause and having the will to bring such outcomes about. Thus, if a judge, when resolving a contention between merchants, makes allowances for the impact that one decision or another will have on the development of trade (if it became a general norm), they demonstrate that they deem that development desirable from the standpoint of legal policy and have a "will" to support that particular social function. If, in a dispute between workers and their employer, the judge considers the needs of the national industry, the resulting decisions are again based on the moment of "will”. In principle, the traditional school negated the existence 
of the element of "will” where judicial rulings were concerned, as it reduced everything to logical, rational factors, to examination of the "legislator's will” irrespective of the consequences and subjective assessments. However, things were different in practice, and total elimination of the purpose factor proves impossible in this domain. A principle to which one adheres in England states that the judge is not bound by a statute if it leads to absurd outcomes. The rule which thus applies there is "lex falsa lex non est"! ${ }^{28}$ The rule which in principle operates on the continent in "lex falsa lex est", but in practice it is modified by various devices, which is due to the effect of the factor of "will". ${ }^{29}$

The third critical element involved in taking juridical decisions is the intuitive factor of legal sense. This consists in reflex-like, impulsive response to human actions from the legal standpoint, in perceiving them to be lawful or unlawful in accordance with the norms universally in force or not. There can be no doubt that the judge, in their appraisal of human actions behind the contentious issue, is subject to spontaneous emotional reaction which is largely unconscious, but which involuntarily induces them to rule in one way or another. Even such a positivist as Ihering, inclined as he is to account for everything by invoking conscious goals, acknowledges that "as a rule, the sense of rightness precedes knowing." ${ }^{30}$ Legal sense has a paramount significance for the functioning of social life and the legal framework. One can hardly imagine the normal coexistence of people without that factor, for sustained conformance with the law is by no means dependent on exact knowledge of its provisions - which is impossible - but consists in being guided by the legal sense inculcated by a given environment. Social

28 E. K. Gerland, Die Einwirkung des Richters auf die Rechtsentwicklung in England, BerlinLeipzig 1910, p. 21.

29 From a strictly psychological position, will to adhere to the statute also comes prior to the intellectual function. However, I choose to stress that factor outside the boundaries adopted in the theory, since teleological considerations—objective criteria being absent—will ultimately always depend on the element of will.

30 R. von Ihering, Geist des römischen Rechts auf den verschiedenen Stufen seiner Entwicklung, Leipzig 1852, p. 353. 
education imparts a range of relevant impulses which inform the right way to conduct oneself.

The combination of legal sense with actual conduct that consistently follows a particularly oriented pattern is at the root of the complex phenomenon of customary law, which tends to be explained in such diverse ways. That optio necessitatis, which the authors of customary law often cite, relies in actual fact on opinis iuris; this is legal sense. Without this factor, the existence of customary law and its difference from custom cannot be explained. Also, it facilitates understanding of dispositive customary law.

I cannot go into the origins or the formation of legal sense. There is no doubt, however, that Ihering's assertion: "nicht das Rechtsgefühl hat das Recht erzeugt, sondern das Recht das Rechtsgefühl“31 has no grounds in fact. Anthropologists and sociologists (Tylor, Maine, Dürkheim, Worms etc.) are in agreement that all societies, even those at the lowest level of development, have legal norms which are universally binding, few though they may be. We do not know and we cannot imagine a society without law. Now, given the fact that primitive law is a customary law which by default contains the element of legal sense, therefore there can be no temporal contrariety between law and legal sense, and the question of the emergence of the latter comes down to the question of the creation of law. Nevertheless, this last question cannon be satisfactorily answered with the current state of knowledge, as the origins of the human and the first social groups are uncertain. Only detailed knowledge of human provenance and the formation of human society can enable productive, sociological inquiry into the genesis of law and legal sense. For us, the certainty that legal sense has existed in all societies and in all periods should suffice.

This may be seen in various forms when justice is administered. For the most part, it arises unconsciously, in advance of the arguments of reason. As we know from history, the famed jurist Bartolus would first

31 R. von Ihering, Der Zweck im Recht, Leipzig 1877, p. X. 
resolve an issue and then ask his friend Tigrinius to find relevant passages in Corpus iuris as he "had poor memory". Legal sense often evinces itself in the guise of "general legal principles", "the nature of things", "rightness" etc. The latter notion in particular tends to be identified with legal sense, though somewhat incorrectly, because "rightness" is a much more capacious term, since it relates not only to the procedure but many other manifestations of life (e.g. wrong reasoning, unwarranted wish) and generally denotes approval, the recognition of certain facts which may appertain to law, but may also be independent. ${ }^{32}$ Legal sense, on the other hand, is a psychological phenomenon, demonstrating specifically and exclusively in connection with law, and having a significant bearing on adjudication.

Legal sense also plays a momentous role in the domain of legislation. From the psychological standpoint, the creation of laws is influenced by two factors: considerations of purpose and legal sense. The legal sense of a period is especially revealed in its fullness in civil law statutes, which decisively affect the creation of binding norms. Certain authors ${ }^{33}$ recommend the enhancement of teleological factors by making civil policy a science which studies the legal means that can enable one to accomplish certain social goals, thus guiding the legislator. If such a branch of knowledge were to develop, it would reduce the role of legal sense but it would not eliminate it entirely, because considerations of purpose also needs to take that factor into account. The historical school embraced legal sense to a considerable extent, but comprehended it onesidedly, disposing completely of the teleological moments and lending it the mystical garb of "national spirit"; this elicited the positivist response which opted for the opposite extreme and began to ignore this factor.

Legal sense has a creative dimension, but it can also be critical and destructive. In the political life of societies, one not infrequently sees how

32 As aptly observed by Prof. Zoll who nonetheless approaches the matter differently. F. Zoll, Austriackie prawo prywatne. Część ogólna, Kraków 1909, p. 33.

33 L. Petrażycki, Die Lehre von Einkommen, Berlin 1885. 
this factor interacts with the applicable law. We often happen to hear that a statute is "unlawful" (e.g. expropriation in the Prussian partition), which does not mean anything other than a contradiction between a law and the existing legal sense of individuals or social groups. Where it generates tension, the conflict between the predominant legal sense and the law in force causes a violent reaction, a powerful outburst that culminates in the phenomenon of revolution. As the previous legal order is abolished, the factor of legal sense-previously critical and destructive-becomes creative, normative, and shows the right path to a new legal framework. One must not claim that this factor is the only one since teleological aspects also play an eminent role, but it is an inextricable element which combines with other factors, either consciously or involuntarily.

It is a matter of some wonder that a factor of such magnitude has thus far not received the scientific appreciation and scrutiny it is due. The existence of the very fact had already been stressed by Grotius, who speaks of law "ad quod a natura nostra nos duci sentimus" ${ }^{4}$, but deliberations of that kind have largely been approached by philosophers of law in a rational fashion, the most vivid example of which is Kant's theory. ${ }^{35}$ Very often, the phenomenon was reduced to a manifestation of metaphysical being. ${ }^{36}$ To date, no one has embarked on a thorough inductive-psychological study of the nature and reifications of legal sense as a real, empirical fact which played a tremendous role at the lower levels of cultural development and still plays it today. ${ }^{37}$ One of the possible future sciences that could render invaluable services to jurisprudence

34 H. Grotius, De iure belli ac pacis, Proleg. § 18.

35 “Alle sittliche Begriffe völlig a priori in der Vernunft Ihren Sitz und Ursprung haben; in dieser Reinigkeit ihrer Ursprunges eben ihre Würde liege”. I. Kant, Grundleg. zur Metaphysik der Sitten, 1785 Riga.

36 "L’origine e la natura delia coscienza del giusto é essentialmente un problema d'ordine metafisico”. G. Del Vecchio, Il sentimento giuridico, Milan 1908, p. 12.

37 Precursory instances of such research may be found in the compelling works by Petrażycki though their critical part is more worthwhile than the positive one. L. Petrażycki, Wstęp do nauki prawa imoralności, 1907, L. Petrażycki, Teorya prawa ipańtwa, Saint Petersburg 1907. 
is legal psychology, which should remain closely associated with the sociology of law.

It has become customary in contemporary science to classify legal sense among ethical phenomena, in the domain of morality. Petrażycki extensively elaborates on the view that intuitive law (which in Petrażycki's writings denotes a phenomenon closely resembling that which we call legal sense) is identical with justice, that the two notions overlap completely. Both phenomena represent normative psychological experience, namely imperative-attributive emotions which incorporate the element of duty and the element of entitlement but are nonetheless independent from positive regulations. ${ }^{38}$ This mingling of two notions which, though linked, are by no means identical, cannot be considered felicitous. Justice is a much broader notion that transcends the realm of law as it refers both to the religious sphere and phenomena that are independent of human will (since injustice is a term we use to describe e.g. physical or intellectual inequality between people). On the other hand, justice displays an individualizing nature while law is universal; hence an act may be in keeping with the legal sense but go against the sense of justice (e.g. demanding payment of debt when the debtor is facing exceptionally adverse circumstances). Legal sense is a social-psychological phenomenon which arises on the grounds of law in the positive sense, therefore it should not become entangled in the domain of morality. Still, they should not be contrasted either, as both constitute two angles of approach to the analogous sphere of human phenomena and actions. Legal and moral sense could be envisioned as two overlapping circles which share a certain surface and have their separate parts as well. Although legal and moral sense are largely (but not always) in concordance, their distinct nature should be emphasized. Underlying both phenomena is a typically human psychological traitthe awareness of the norms of conduct. One of the reasons why the notions tend to be thus confused is language, the linguistic chaos caused

38 L. Petrażycki, Teorya prawa i państwa, Saint Petersburg 1907, pp. 500-508. 
by the usage of the words "law", "legal sense" and "moral sense". However (as Petrażycki adroitly demonstrated), science is concerned with phenomena rather than with names, and linguistic custom is no major indication in the realm of universitas scientiarum. In the opinion of this author, legal sense constitutes a something which, sui generis, is a phenomenon of juridical nature, regardless of whether individuals call it law or morality.

At this point, we should not delve ay deeper into the philosophicalpsychological issues. For the current purposes, it suffices to state the three psychological factors which accompany the exercise of the judicial function: 1) intellect (logical adjustment to achieve alignment with statutes), 2) legal sense, and 3) will (teleological considerations, determination of social goals and legal means).

If we now reconsider the tenets of legal modernism and the historical school, we will clearly see how both trends approach the psychological phenomena we have just discussed. The search for the legislative will, be it explicit or presumable, should proceed by way of reason while dismissing any other arguments. The creation of juridical science should only rely on the objective factor of intellect. Obviously, things were different in practice, but the theory recognized only rational operations, only logical constructions. The drawback of that method (in its pure form) is the necessary rift between social needs and the "will of the legislator", between the demands of the present day and the position adopted when a law was drafted. Here, law should be inflexible and obsolete. Furthermore, it is a one-sided position, as it does not allow for the remaining two factors which, as we have seen, actually play a momentous role.

Modernism gives precedence to feeling and will. Teleological aspects, the purposefulness of norms, is considered decisive, as law is merely a means for attaining certain social goals, and modern needs should be the sole criterion. Therefore, it emphasizes the necessity to democratize jurisprudence, to introduce harmony between public legal awareness and the regulations in force, as it believes to be able to 
achieve that end by leaving judges at complete liberty to rely on their feeling and will. It is a weakness of that trend that it does away with the intellectual element (as we understand it) altogether, relinquishes logical connection with the applicable statute, and thus utterly eliminates the objective factor. This leads to extreme subjectivity and latitude, and also precludes legal security. Apart from that, the position is also onesided because logical harmony and the link with the existing regulations must be retained if judicial rulings are not to be revolutionary in their nature (which the modernists by no means call for).

As we can see, from the legal-philosophical standpoint as well as in the light of the essence of law, its principal postulations (social purpose and objectivity of norms) display major shortcomings; the flaw of the first is that the norms are all too rigid (do not correspond to life), whereas the others are too subjective (liberal). The appropriate method should allow both for the vital demands of law and actual elements of human psychology which exert their impact in life; it should strive —as far as possible - to reconcile those two facets of legal phenomena. The task of the correct method would thus be to modernize the intellectual factor and render the factors of feeling and will more objective.

First of all, let us see if that is feasible with respect to the most crucial element of the modernist trend, that is the factor of will. Can there be guidelines, or lodestars that would objectively show the judge which relationships they should deem the most valuable and worthy of being endorsed by law? Are there or can there be pertinent criteria which harbour a universal value? Social good is an essential goal that tends to be very widely recognized as such. Yet, as we know, this is a term which speaks volumes but defines little, a flexible notion which can be construed in the most diverse ways. Quot capita, tot sensus. Virtually everyone who deliberates on those issues entertains different views with regard to legal means leading to the public good, to the benefit of all. Indeed, there are theories that advance guiding rules which should govern the creation of law. However, should it be Stammler's formula (Gemein- 
schaft frei wollender Menschen)? The fostering of altruistic impulses and the feeling of love (Petrażycki)? A legal rule based on the principle of solidarity (Duguit)? Or the development of culture of a given period (Kohler, Berolzheimer)? Evaluation of particular institutions in the light of the course of development (Liszt, Makarewicz)? Undoubtedly, many of these factors on which the theories are founded should perhaps be taken into account. Still, I do not believe that any of the suggested directives can be deemed the one and only criterion. This is even more difficult given that the above theories apply to legislative policy rather than the objective we are concerned with-addressing statutory loopholes. Perhaps a science of civil-interpretative policy to advise judges, modelled for instance on Petrażycki's "civil policy”, will develop with time. There is also no doubt that accurate knowledge of social life and awareness of the achievements of modern science reduces the difference in value assessments of the factual material. However, the factors of social purpose or will must remain more or less subjective, and this cannot be mitigated by even the subtlest philosophical constructs. Ultimately therefore, the refinement of the judge will be decisive, and that cannot be replaced by any guidelines or norms.

If the factor of will (social purpose) cannot be made thoroughly objective, this does not mean that modernists are right in demanding complete freedom of the judge. Unqualified licence of the representatives of Themis cannot be admissible from the legal viewpoint. The total liberty of judges would result in the universal uncertainty of transactions, allegations of partiality, and severely undermined confidence of the public in the impartial judiciary. If it is impossible to formulate objective, universally recognized directives that would regulate the actions of judges, then one can and should define the boundaries of their discretional manifestations. One should delineate the confines, establish a framework within which lawyers are at liberty to determine social purpose, but beyond which they cannot go for reasons of public security. Such boundaries may be set by two other factors (intellect, feeling), as long as they are correctly construed. 
As already noted, the intellectual factor consists in adjusting legal decisions to the existing laws. This consonance with the applicable regulations (when addressing statutory lacunae) must be retained, although it should not mean the fictitious "will of the then legislator" but rather the actual "position of the contemporary legislator". The issue here is not devising artificial constructs that serve to examine how the present-day legislator sees a given issue, as that would be impossible due to numerous factors-exceedingly complex and unpredictable in themselveswhich affect the enactment of statutes. The matter should be approached in a juridical fashion, using pertinent methods of jurisprudence, so as to determine the position of the contemporary legislator in the light of the entirety of laws, including both codes and more recent acts of legislation. The idea here is to take heed of ratio iuris, or the legal principles and concepts which provide the point of departure, the foundation of statutory provisions. Since social views and legal principles evolve and change over time, the views and legislative principles which are closest to the present times should prevail; in other words, moderna ratio iuris decides. For this purpose, a new principle should be introduced alongside the old tenet of lex posterior derogat priori: ratio iuris posterior derogat priori. For instance, if Napoleon's code stipulates almost unlimited freedom of contract, more recent statutes demonstrate a shift towards protection of the economically disadvantaged classes, and when resolving a particular case, when formulating a legal norm, the latter position of moderna ratio iuris is decisive. Thus understood, the intellectual factor is not contrary to the essential postulations of the modernists concerning due regard for the new social relationships, and at the same time has the great advantage of assuring legal security by establishing boundaries for judicial discretion. Most likely, analogous concepts are at the root of Paragraph 1 in the Swiss code which, in the event of statutory loopholes and the absence of pertinent customary law, entitles judges to rule according to a norm they would formulate as a legislator, whilst taking tradition into account. Here, logical compliance and consonance 
with the essential foundations of the existing legal order are observed as well.

The second psychological factor, which assumes various forms in the modernist postulations, is legal sense. It is found in all people, in all societies, but its manifestations tend to be very diverse. The legal response to human action is by no means uniform, not only at various levels of cultural development but even in the same civilizational period. Legal sense is a highly subjective moment and, in the form posited by modernists, it cannot be accepted as a principle of adjudication, as an objective norm.

Let us briefly consider the essence and nature of legal sense, referring to our earlier observations in this respect. It is not only psychological but also a social phenomenon, arising in equal measure from social education and life, and the idiosyncratic nature of a given individual. It would therefore follow that legal sense has two components: the individual and the social one. Thus, we can speak of individual legal sense and social legal sense.

The first phenomenon results from a whole plethora of factors, including the influence of the social system and the general conditions in which members of a given social group happen to function, as well as a range of special circumstances affecting the individual, such as family upbringing, one's milieu, the literature one has read, their views, temperament, life experiences and so on. The sum of all those factors makes up the psyche of the individual and the peculiar legal sense marked by their individuality. This leads to differences of opinion and in the legal assessment of the same factual material, which are sometimes very profound.

Still, human beings are social creatures and are therefore not alien to the trends that occur within society. Thus, their psychology is exposed to views, beliefs, and customs circulating in the community which, mirrored in their minds, leave indelible traces. From the earliest years, the entire upbringing of children consists in instilling such patterns of thinking, feeling, and acting which no doubt would not have developed spon- 
taneously; all efforts are aimed at making them social beings. Even the greatest individualists cannot divest themselves of the spiritual elements and impulses which have been inculcated by society. The very idea of individualism is a product of social life developed over time and which is unknown in the lowest tiers of civilization. As Comte very aptly put it: "L'homme se developpe collectivement et point individuellement." The part of our "self" which is truly autonomous, truly independent from society is so negligible that it plays a more serious role only in exceptional, outstanding personalities. What is more, a powerful manifestation of individualism which is at odds with social notions usually provokes an intense public response, and it is not unusual for the pioneers of novel ideas to become their martyrs. The presence of social-psychological phenomena which occur in the entire society and, in a sense, beyond individuals themselves, is so evident that it became the foundation of a whole sociological school (Durkheim, Bouglé, etc.), which nevertheless goes too far in presuming that these phenomena constitute external compulsion and exist separately and independently of the individual psyche. ${ }^{39}$ Among the various social-psychological phenomena, social legal sense takes one of the foremost places. It represents the outcome of the entire legal system within which each citizen lives and develops, the upshot of all conditions created by statutory and customary law, of the whole configuration of social life. It may differ from period to period and from peoples to peoples, but in a given society it remains uniform for all, or at least for the majority of its members. The most eloquent reification of the social legal sense is customary law, whose pre-requisite is the conviction of lawfulness shared not by particular individuals but by the entire community (or specific groups). While customary law cannot exist without social legal sense, the reverse is not out of the question. It is possible for a specifically oriented social legal sense to exist without being actually exercised (e.g. due to statutory obstacles).

39 E. Durkheim, Les regles de la methode sociologique, Paris 1910, p. $19 \mathrm{ff}$. 
Social legal sense is not independent of the individual psyche. It only means a certain set of psychological elements that are common to the entirety of a given social group. Thus, an individual legal sense is narrower with regard to the subject, being attached to one person only, but it is broader in terms of its object, because it comprises social legal sense as well as particular traits of the individual. It may be conjectured that in the legal sense of an average citizen social elements outweigh individual ones, which is due to the nature of the phenomenon as it tends to create norms imposed coercively on everyone and therefore induces adjustment of one's singular legal sense so that it conforms with the views of the whole social body.

It follows from the above that the psyche of the judge (or theoretical jurist) contains legal sense made up of two elements. The question then is which of those elements proves decisive in the administration of justice: the personal or the popular, the individual or the social one? This, surely, is no major quandary. Judges do not approach jurisprudence from the standpoint of the peculiar emotional traits of particular individuals, but as exponents of the common views and social sentiment. In the administration of justice, social legal sense is the only one which can be taken into account. Thus the factor of feeling, which already plays a serious role today, becomes an objective factor and establishes the limits of discretion for the actions of the judge. The postulation of the modernists concerning integration of the judge's legal sense into the process should be thus modified in order to become a genuinely objective directive and a boundary in adjudication. This is no radical reform but a refinement of the process which is already taking place. Here, one can also refer to Paragraph 1 of the Swiss code, which sets forth that in the case of statutory loopholes the judge shall take customary law into account. If we extend that last notion and exclude the requirement of sustained actual application, we arrive at social legal sense. Undoubtedly, conclusive determination of that condition is severely hindered. It obliges the judge to step outside their office and look into social life so 
as to gain insight into its currents. Nevertheless, as a general guideline it is an inevitable consequence of the modernist postulation to make law more social. Perhaps the evolution of the judiciary will lead to greater specialization and produce professionals who are conversant with certain areas of social life and related needs. After all, effective application of the above factor-as well as others-ultimately hinges on judges' knowledge and their tact.

Thus we arrive at the general conclusion of our disquisition: if contemporary social needs are to be duly considered in jurisprudence and the administration of justice, the judge must necessarily be at liberty to make their assessments, which must be more or less subjective. However, for reasons of legal security, certain boundaries to subjective assessments must be introduced, and these will be supplied by two other factors: 1) the intellectual factor (alignment with the existing legal order), and 2) the factor of feeling (social legal sense). If determination of the social purpose or needs is problematic in a given case, the above factors offer directives which facilitate the task of the judge. However, if the assessment of the judge is definite but too individually or subjectively tinged, the above factors ensure the boundaries within which autonomous discretion is not suppressed, but which should not be overstepped. These are safety constraints, put in place in the interest of the stability of the legal order.

We shall therefore formulate our position in the following manner: In situations for which the statute does not provide, the judge should freely determine the norm which will be the most appropriate in view of social needs, taking into consideration the position of the contemporary legislator (moderna ratio iuris) and the social legal sense.

Finally, I would like to touch upon an issue which thus far has not been discussed with respect to the development of the modern trend, but remains closely associated, and even arises from it by way of consequence. We have said that making legal decisions should involve social legal sense. Obviously, this means the legal sense of the social group where a given contention takes place. Thus, in issues relating to industrial 
labour one cannot seek legal sense among farmers, nor rely on the conviction of tradesmen in agricultural disputes. However, there is a social group whose significance in terms of legal sense is superior: this group is the nation itself, and the national legal sense is the respective phenomenon. It is not the mystical "Volksgeist" of the historical school, their alleged sole factor behind the creation of law, but a distinct manner of understanding, feeling and responding to the phenomena of the external world. There are various views relating to the issue of nationality, and the definitions are just as diverse. However, as the phenomenon evolves and the thoroughness of dedicated studies increases, it becomes more and more evident that the essence of nationality in the contemporary sense should be sought in the sphere of psychology. The opinion expressed by Renan $^{40}$, who states that "Une nation est une âme, un principe spirituel”, aptly captures the pivotal moment of that phenomenon. Specific history, different customs, views and beliefs yield a distinct national psyche. Each nation has its peculiar fashion of comprehending things and a dissimilar normative sensibility; each has its national psyche. Bearing in mind that legal sense is a component of the general psychological make-up, each nation possesses a singular national legal sense, which also needs to be contemplated when laws are applied. The existence of that factor becomes even less doubtful when we observe that nations today are a result of joint living in the community of state ${ }^{41}$ and thus in a common legal framework, therefore they must harbour that psychological element which is directly associated with the legal organization: national legal sense. The phenomenon should not be approached as an isolated occurrence, since it is linked to all other currents and manifestations of the national spirit, and constitutes an inseparable ingredient in the national culture as a whole. ${ }^{42}$

40 E. Renan, Qu'est ce que'une nation, Paris 1882, p. 26.

41 "Eine Vielheit von Menschen, die durch eine Vielheit gemeinsamer, eigentümlicher Kulturelemente und eine gemeinsame geschichtliche Vergangenheit sich geeinigt und dadurch von anderen unterschieden weiss, bildet eine Nation”, G. Jellinek, Allgemeine Staatslehre, Berlin, 1905, p. 114.

42 "Plusieurs choses gouvernent les hommes : le climat, la religion, les lois, les maximes du gouvernement, les exemples des choses passees, les moeurs, les manieres; d'ou il se forme 
Under normal conditions, where the state overlaps with the nation, the distinctiveness of the national legal sense does not cause any complications. It is expressed in the legislation, which corresponds with the character of a given nation. States which represent a conglomerate of many nationalities are a different matter. The difficulties seen there owe to the differences between those nationalities, and there is the additional danger of the ruling group forcibly imposing their qualities on all other national groups. "There are two kinds of tyranny," says Montesquieu, "one real, which arises from oppression; the other is seated in opinion, and is sure to be felt whenever those who govern establish things shocking to the present ideas of a nation." ${ }^{43}$ Incidentally, this is not merely a theoretical possibility but a very real phenomenon which is seen in Europe ever more clearly. ${ }^{44}$

The modernist current fails to mention these difficulties, passes over them in silence, and that gap needs to be rectified. Legal differences must be taken into account if the law is to be genuinely "socialized”, if there is to be harmony between regulations and the legal awareness of the broad public. Quite rightly, modernism places concern for social needs at the fore, but there can be no doubt that one of the most striking social needs is recognition of the national traits by adjusting the law so that it dovetails with the psychology of a nation. This is why the modernist trend requires necessary modification along those very lines. The free reckoning on a judge's part should rely on detailed knowledge of views, feelings, customs and beliefs-all the qualities of a given nation-while legal norms should be formulated accordingly. Most likely, the efforts to rectify lacunae and contradictions in the statutes do not satisfy such bias sufficiently. It is also likely that the overall evolution of law will lead to the adoption of the princi-

un esprit général qui en resulte.” C.L. Montesquieu, Esprit des lois, Londres 1777, XIX, 4. 43 C. L. Montesquieu, Esprit des lois, Londres 1777, XIX, 3.

44 Simon Rundstein makes some interesting remarks on that score in Freie Rechtsfindung und Differenzierung des Rechtsbewusstseins. S. Rundstein, Freie Rechtsfindung und Differenzierung des Rechtsbewusstseins, ”Archiv für bürgerliches Recht” vol. XXXIV. 
ple argued by the modernists, namely that statutes should only contain general guidelines which the judge will follow as particular conditions and circumstances allow. In such a case, national differences could be taken into account to a much broader extent. At any rate, the modernist trend requires supplementation with regard to the national aspect. Next to the motto affirming the "socialization of law!", another principle should be posited: the "nationalization of law!"

Of all the stateless nations, the strongest awareness of national distinctiveness has been preserved among Poles. Hence one could assert a priori that the Polish legal sense is characterized by exceptional potency. It is true that the long-lasting abnormal political state has to some degree undermined the cohesion of the national psyche and disturbed the Polish legal sense. Nonetheless, the distinctiveness endures and tends to be very vividly evinced in some regions. However, the phenomenon has not been systematically studied, and the yield of Polish science displays major deficits in that respect. Inquiry into the nature and manifestations of Polish legal sense in the light of our historical past and in connection with the entirety of our national culture should be one of the chief tasks of Polish jurisprudence. Only thorough knowledge of one's society can enable the application of law that is attuned to its needs and national qualities.

With respect to the modernist trend, which is now transitioning into a Europe-wide current, Poland should not be passive and merely receptive but contribute its own postulation, a novel factor, namely the nationalization of law.

\section{Literature}

Bergbohm C., Jurisprudenz und Rechtsphilosophie, Leipzig 1892. Bozi A., Die Weltanschauung der Jurisprudenz, Hannover-Helwing 1911. 
Bülow O., Heitere und ernste Betrachtungen über die Rechtwissenschaft, Leipzig 1901.

Del Vecchio G., Il sentimento giuridico, Milan 1908.

Del Vecchio G., Sulla positivita come carattere del diritto, Prolusione al corso di Filosofia del diritto, Bologna 1911.

Donati D., Il problema delle lacune dell ordinamento giuridico, Milan 1910.

Durkheim E., Les regles de la methode sociologique, Paris 1910.

Gény F., Méthode d'interprétation et sources en droit privé positif: essai critique, Paris 1899.

Gerland E. K., Die Einwirkung des Richters auf die Rechtsentwicklung in England, Berlin-Leipzig 1910.

Grotius H., De iure belli ac pacis, Proleg. § 18.

Ihering R. von, Der Zweck im Recht, Leipzig 1877.

Ihering R. von, Geist des römischen Rechts auf den verschiedenen Stufen seiner Entwicklung, Leipzig 1852.

Jellinek G., Allgemeine Staatslehre, Berlin 1905.

Kant I., Grundleg. zur Metaphysik der Sitten, Riga 1785.

Kantorowicz H., Die Contra-legem Fabel, "Deutsche Richterzeitung“ 1911, no. 8.

Kantorowicz H., Kampf um die Rechtswissenschaft, Heidelberg 1906.

Montesquieu C. L., Esprit des lois, Londres 1777.

Petrażycki L., Die Lehre von Einkommen, Berlin 1885.

Petrażycki L., Teorya prawa i państwa, Saint Petersburg 1907.

Petrażycki L., Wstęp do nauki prawa i moralności, Petersburg 1907.

Radbruch G., Rechtswissenschaft als Rechtsschöpfung, Heidelberg 1906.

Renan E., Qu'est ce que'une nation, Paris 1882.

Rundstein S., Freie Rechtsfindung und Differenzierung des Rechtsbewusstseins, "Archiv für bürgerliches Recht”, vol. XXXIV.

Sigwart S., Logik, Freiburg 1889.

von Jhering R., Jahrbücher für die Dogmatik des heutigen römischen und deutschen Privatrechts, Jena 1857. 
Windelband W., Präludien, Aufsätze und Reden zur Einleitung in die Philosophie, Freiburg 1884, p. 265.

Wundt W., Logik der Geisteswissenschaften, Stuttgart 1908.

Zoll F., Austriackie prawo prywatne. Część ogólna, Kraków 1909. 
